\title{
Woman's Voice Speaks Out for Gender and The Environment in Gadis Pesisir
}

\author{
Hiqma Nur Agustina* \\ English Department, State Polytechnic of Malang
}

\begin{abstract}
The life of women in Indonesia's coastal areas tends to have limitations in accessing education. They are a minority group who often have to stay at home and do domestic work. The purpose of this paper is to explore the environmental issue, ecological, mixed with feminist criticism in Gadis Pesisir, a short story by Zainul Muttaqin. By defining the woman's minimum role in studying at the college and her desire to develop the coastal society, the author exposes the contrast between them, related to the coastal welfare and cultural conflicts between the gender relation and the spirit to advance the community. This research is a descriptive qualitative method that uses library research. Ecocriticism and feminist criticism are highlighting the interaction among literary text, nature, and women's voices. By raising this local issue, the writer described the women empowerment loss of patriarchy culture. This short story perpetuates the powerlessness of coastal women in fighting patriarchal culture, stigma, and the marine environment. They can only dream and wait for a miracle to change their destiny. It is contrary to women's rights which are fought for by feminists on the equality of women and men in accessing education, obtaining job opportunities, and careers in various fields.
\end{abstract}

\section{Introduction}

The issue of the environment is a timeless problem. Moreover, humanity's awareness to protect the environment also does not always run consistently and continuously. Raising ecological issues in essays, articles, and books becomes a plural thing done by many people. One of them appoints in the form of short stories that are identical to literary works. Sudewa called it green literature for the study of literary ecology [1]. According to him, the study of literary ecology seeks to reveal how environmental issues are explored in literary works by writers. Ecocriticism launched a call to literature to connect to today's environmental crisis [2]. Wiyatmi called green literature a literary genre that deliberately carries the main themes of ecological issues, human relations with nature, and the environment [3]. According to Oppermann, applying ecology or ecological concepts and themes to literary criticism is an enhancement of literary studies [4]. Contemporary novels have used parallel paradigms between ecology and literature, which await detailed critical exploration and evaluation in an interdisciplinary approach of ecocriticism.

\footnotetext{
*Corresponding author: hiqma@polinema.ac.id
} 
Ecocritical theory collaborates between literature and ecology. Literature deals with imaginative things, but literature sometimes discusses reality. Ecology discusses environmental, social, political, and cultural issues or issues [5]. According to Fauzi, nature is a bridge for authors and literary works to convey the atmosphere, images, settings, or major themes in literary works [6]. Maria Matildis Banda states that literature is a way out of various humanitarian conflicts, a means of reconciliation [7].

The link between nature and literary works raises many literary works that then raise natural issues. Literary ecocriticism is the study of the relationship between literature and the physical environment [8]. Garrard states that ecocriticism can help determine, explore, and even solve ecological problems in a broader sense [9]. In its function as a media representation of attitudes, views, and responses of the community to the surrounding environment, literature can express ideas about the environment, including the values of environmental wisdom. It is very reasonable considering the literature grows, develops, and sources the community environment and the natural environment (ecological).

Some literary works as a representation of literary criticism try to show the writer's efforts to raise environmental damage, environmental phenomena such as water pollution, forest destruction, natural disasters in the form of landslides. The event shows the exploitation of nature that resulted in fatalities - these environmental issues raise into literary work [10]. A literary work sometimes appears because of a phenomenon that occurs in society and then reveals the reality of real life.

Some short stories that raise environmental issues appear in several newspapers in Indonesia, such as Kompas, Republika, Jawa Pos, Tempo, Suara Merdeka, and several other names. Several researchers have also carried out research that raises environmental issues. For example, Banda, who examined the whaling fishermen community [11], Tripathi and Bhattacharjee studied the texts of Thomas Hardy and Charles Dickens [12], Juanda discussed short stories that take the theme of the damaged environment [13], Bizuum, Manasseh and Vashti examined the issue of environmental damage and reclamation [14]. The study examines different texts and also different problems. Therefore, Gadis Pesisir, as the primary data of this study, are interesting to study. They raise the struggle of a girl who wants to continue attending school at the university level but rejected her father. He lives in the coastal area in Indonesia because of the patriarchal culture that tends to repress women. The aim is to continue attending school in the fishery sector to improve the lives of fishers by learning to make canned fish that automatically raises the selling price of sea fish [15].

Some research about ecocriticism with literary works only focuses on the figure who positions as a saviour concerning ecologies such as forest fires, erosion of land, and flooding due to human greediness. This research is in literature because it examines short stories, social science. After all, it examines women's problems in society and environmental science because it examines the relationship between the environment and humans. Therefore, research results expect to have a contribution to the development of interdisciplinary science.

\section{Ecocriticism and Feminist Criticism in Gadis Pesisir}

Ecocriticism arises because of the concern of experts on the issue of environmental damage on earth. This concern is tangible in the form of concrete actions and demonstrations of environmental damage caused by factories, companies that do not process waste, and waste properly to damage the environment. However, this concern also followed writers who put ideas and ideas into writing to create short stories. The exciting thing is when two issues are raised and then clashed in a text. Gadis Pesisir raises issues about the environment and women in distinctive colours. Therefore, this paper will specifically use two approaches to study it, Ecocriticism and Feminist criticism. 
Women's voices, social conflicts, and ecological problems are criticisms carried by Zainul Muttaqin for readers. Gadis Pesisir presents ecological problems, the lives of fishers in the coastal areas, and local culture, which is load with patriarchy. Environmental understanding, cultural sociology, and literary studies are needed to understand this short story. This short story carries the message and theme of the struggle of a woman who wants to get out of a patriarchal culture that often constrains women's independence and at the same time elevates the lives of fishing communities that have not touched modernity and technology.

The woman character and narrator in Gadis Pesisir's short story is named Nur. Her willingness and high desire to continue attending school at the university level do not condone by her father. The views and principles of her father's life uphold patriarchal culture, resulting in Nur having to bury her dream to study at the Department of Fisheries at the university. Women do not need to go to high school and stay at home and only carry out activities in the kitchen, from cooking rice to serving coffee for the father. Her father's rejection of Nur's desire to go to college can see in the following quote.

"Kalau kau kuliah? Siapa yang bantu Ayah di sini? Lagian tak perlu perempuan sekolah tinggi-tinggi. Sudah banyak sarjana menganggur. Di sini kau lebih bermanfaat," begitu ayahnya selalu menukas kepada Nur tiap gadis itu mengutarakan niatnya.

"If you go to college? Who helped Dad here? Besides, there is no need for high school girls. Many scholars are unemployed. Here you are more valuable, "so her father always said to Nur that each girl expressed her intention.

The quote above shows Nur's character trapped in gender stereotypes that women do not need to go to high school. In other words, gender stereotypes position women only in the domestic sphere. This type of stereotype is often a factor causing social problems in discrimination between men and women. Women often experience discrimination due to the division of roles which tends to lead to gender inequality. The two criticisms presented in this short story make this work meaningful to fight for the role of women in coastal areas. Nur's desire to become a woman who is empowered with her idea to increase the income of fishers through fish canning is a form of her efforts to criticize marine culture that tends to negate the role of women in the public sphere.

\section{Patriarchy Culture in Coastal's Society}

Patriarchal culture, which is identical to repressing women, makes women consistently weak, helpless, and victims of injustice. Walby explains that patriarchy is a system of social structures, practices that place men in a dominant position, oppressing and exploiting women [16]. Walby made a theory about patriarchy. Patriarchy can divide into two, namely private patriarchy and public patriarchy. According to him, there has been an expansion of patriarchal forms from private and private spaces such as family and religion to a broader area, namely the state. This expansion caused patriarchy to grip and dominate the lives of men and women constantly.

Through the voices of characters and narrators, the writer deconstructs the patriarchal power that causes natural disasters and damage. Gadis Pesisir becomes agents to deconstruct the view that nature creates to be utilized by humanity as an asset and commodity that can be explored and exploited on a large scale. Gadis Pesisir presents the social critic of the author of the lives of fisher on the coast that has not been touched by modernization and technology so that their lives are imperfect. The results of catching fish are often valued cheap because 
there is no hygienic and modern fish processing system or investors to improve the quality of fish processing.

Women's subordination begins with the division of labour based on gender and is related to the function of women as mothers. Women's ability used as an excuse to limit their role to the domestic and child care roles.

“Buat apa sekolah? Perempuan itu tempatnya di dapur!” lanjut ayahnya. Raut mukanya terlihat keruh. Nur menjatuhkan pandangan ke pangkuan bumi.

"What is a school? That girl is in the kitchen!" continued her father. His face looks murky. Nur dropped her eyes into the lap of the earth.

The above quotation emphasizes the subordination of women to only be in the domestic sphere. Schools do not belong to women; schools are only for men. Women's voices echoed by male writers to counter stereotypes that often pin on women attempted. The author examines women's lives in coastal areas who are still exposed to poverty and the lack of women to get their rights to continue attending school. When technology and modernization are spreading in all corners of the world, there should be no difference in opportunities for men and women. They have the same right to get an education at the highest level, namely at the university.

\section{Conclusion}

Gadis Pesisir is a short story presented by the writer to voice the role of women in the public sphere. There are stereotypes and subordination often experienced by women as represented by Nur's character, especially in coastal areas. Her desire to gain knowledge about modern fish processing technology did not get a response from her father. This short story that raised the issue of ecology aims to improve the living standards of fishing communities in Indonesia's coastal areas and raise social issues about women's role is still less in marine society. Women became the victim because of patriarchy, stereotype, and subordination. The poor fishers are always in the lowest social stratification. The technology will help them in organizing the fish into modern packaging's, such as canned fish. The fishers need to change their mindsets about education, technology, and modernity.

\section{References}

1. K. Sudewa, Sastra Hijau sebagai Wahana Pembelajaran Sastra Berbasis Lingkungan, (Universitas Udayana Denpasar, 2017)

2. C. Glothfelty, H. Fromm, ed The Ecocriticism Reader: Landmarks in Literary Ecology. Athens (The University of Georgia Press Georgia \& London, 1996)

3. Wiyatmi, Ekofeminisme: Kritik Sastra Berwawasan Ekologis dan Feminis, (Cantrik Pustaka Yogyakarta, 2018)

4. S. Oppermann, Ecocriticism: Natural World in the Literary Viewfinder (Hacettepe University Journal of Faculty of Letters), 16(2), 29-46 (1999)

5. Juanda, Exploitation Phenomena in the Environmental in the Short Stories Weekly Newspaper in Indonesia with Ecocritic Approach, AKSIS Jurnal Pendidikan Bahasa dan Sastra Indonesia, 2(2), (2018)

6. A. A. Fauzi, Kritik Ekologi dalam Kumpulan Cerpen Kayu Naga Karya Korrie Layun Rampan melalui Pendekatan Ekokritik, Skripsi Universitas Negeri Yogyakarta, (2014) 
7. Rahmat, (December, 2019), Dialog “Sastra dan Kemanusiaan” Bersama Maria Matildis Banda, Retrieved from https://balinesia.id/read/dialog-sastra-dan-kemanusiaan-bersamamaria-matildis-banda

8. C. Glothfelty, H. Fromm, The Ecocriticism Reader: Landmarks in Literary Ecology (Georgia \& London: The University of Georgia Press, 1996)

9. G. Garrard, Ecocriticism, (Routledge New York, 2004)

10. M. M. Johari, M. T. Zulkifli, Environmental Issues in the Literary Work [of] Malaysia: Preliminary Study of Sarawak Novel Writers, World Review of Business Research 1, 4 (2011)

11. M. M. Banda, Proc. Int. Conf. on Literature, 584 (2016)

12. M. Tripathi, R. Bhattacharjee, An Analysis of Ecocriticism and Literature with particular reference to the works of Hardy and Dickens, International J of Eng Lang, Lit and Hum, 4, (2016)

13. Juanda, Pendidikan Lingkungan Peserta Didik melalui Sastra Anak Berbasis Lokal, Proc. Int. Conf. on Literature, 91 (2016)

14. B. G. Yadok et al., Environmental Degradation and Nature's Reclamation: A Study of Yiro's Abari in the Absence of Man English Language Teaching and Linguistics Studies, 2(1), (2010)

15.Z. Muttaqien, (2016), Cerita Pendek: Gadis Pesisir, Retrieved from https://www.femina.co.id/fiction/gadis-pesisir-

16. S. Walby, Theorizing Patriarchy, in Socio J, 23(920), 213-220 (1989) 